\title{
AN ASSAY OF THE ACTIVITY OF SUPPLEMENTARY DNA IN LOLIUM
}

\author{
J. HUTCHINSON, H. REES and A. G. SEAL \\ Department of Agricultural Botany, University College of Wales, Aberystwyth
}

Received 29.vi.79

\begin{abstract}
SUMmary
Inbreeding species of Lolium have about 40 per cent more nuclear DNA than the outbreeding species. Even so inbreeders may be readily hybridised with outbreeders to produce viable $F_{1}$ 's which, in many cases, are fertile, producing $\mathrm{F}_{2}$ progenies on intercrossing or backcross progenies when crossed with the parents.

Recombination between and within chromosomes at meiosis in the $F_{1}$ results in the quantitative segregation of DNA to the nuclei of gametes and of $\mathrm{F}_{2}$ and backcross progenies. An assay of the effects of the DNA variation among these progenies showed no influence of DNA amount upon the expression of 19 phenotypic characters, ranging from early seedling growth to flowering. There was, however, a very slight reduction from expectation in the mean DNA amount of backcross and $F_{2}$ progenies. Apart from this slight effect on viability, either of gametes or of zygotes with high nuclear DNA content, our assay shows that the supplementary DNA fraction which distinguishes outbreeding from inbreeding species has, at most, surprisingly little effect upon the growth and development of the Lolium hybrids.
\end{abstract}

\section{INTRODUCTION}

Speciation, among flowering plants in particular, is often accompanied by massive variation in nuclear DNA amount. Particularly striking are instances which have resulted in very marked differences in nuclear DNA amount between very closely related species. In the genus Lolium, for example, the inbreeding species have about 40 per cent more nuclear DNA than the outbreeders (table 1). Despite the large DNA difference, the

\section{TABLE 1}

Nuclear DNA amounts of Lolium species

\begin{tabular}{|c|c|c|}
\hline Species & Origin of population & $\begin{array}{l}\text { Nuclear DNA amount } \\
\text { pg per } 2 \mathrm{C} \text { nucleus }\end{array}$ \\
\hline Lolium perenne & Cultivar S24 & $4 \cdot 16^{*}$ \\
\hline L. multiflorum & Cultivar S22 & $4 \cdot 31 *$ \\
\hline L. rigidum & U.S.D.A. 239 ex. Iran & $4.33^{*}$ \\
\hline L. canariense & ex. Kew & $4 \cdot 23^{+}$ \\
\hline L. loliaceum & Ba 5164] Welsh Plant & $5 \cdot 49 *$ \\
\hline L. remotum & Ba 8315 Breeding Station, & $6 \cdot 04 *$ \\
\hline L. temulentum & Ba 3081$\}$ accession & $6 \cdot 23 *$ \\
\hline L. persicum & Ba 9163 number & $6 \cdot 35$ \\
\hline
\end{tabular}

* These values are approximately half those published by Rees and Jones (1972) who made an error in converting relative to absolute DNA amounts.

+ Data from S. B. Teoh (unpublished). 
inbreeding and outbreeding Loliums are of sufficiently close genetic relationship to permit hybridisation between them. Most of the $F_{1}$ hybrids, moreover, are fertile, producing $\mathrm{F}_{2}$ 's by selfing or intercrossing and backcross progenies by crossing with either "high" or "low" DNA parents. The DNA variation between the inbreeding and outbreeding Lolium species is not due to a difference in chromosome number. All species are diploids with $2 n=14$. The " extra " or supplementary DNA in the inbreeders is therefore due to the amplification of base sequences within the chromosomes (Rees and Jones, 1967). As a result the chromosomes of the inbreeding species are larger than those of the outbreeders. The genetic significance of the supplementary DNA within the genus or, indeed, within numerous other genera, both of plants and animals, remains largely unresolved. In short, we do not know what effect, direct or indirect, the supplementary DNA has upon the growth and development of the phenotype. We describe, below, an attempt at assaying these effects by examining the phenotypes of individuals with different DNA amounts in $F_{2}$ and backcross progenies from interspecific hybrids in Lolium, progenies in which there is segregation for nuclear DNA amount due to recombination at meiosis in the $F_{1}$.

\section{Materials AND methods}

(i) The assay

When inbreeding Lolium species, with high DNA and large chromosomes, are crossed with outbreeders with low DNA and small chromosomes we expect, and find, the nuclear DNA amount in the $F_{1}$ hybrids to be intermediate between those of the parents (fig. 1). At meiosis in the $\mathrm{F}_{1}$, recombination among chromosomes, by random assortment, and recombination within chromosomes, by crossing-over, will generate gametes with DNA amounts varying from the haploid amount in the low DNA parent, with small chromosomes, to that in the high DNA parent, with large chromosomes. For this reason we expect the progenies from a backcross, $F_{1} \times$ low DNA parent, to have DNA amounts ranging from that in the low DNA parent to that of the $F_{1}$, i.e., the mid-parent value; from a backcross, $F_{1} \times$ high DNA parent, ranging from the mid-parent value to the high DNA parent. We would expect the progenies in $F_{2}$, from selfing or intercrossing $F_{1}$ 's, to have DNA amounts ranging from that of the low DNA parent to that of the high DNA parent. These expectations are based on the assumption that the viability of gametes, and of progenies, are not affected by variation in the amount of the supplementary DNA fraction. Departures from expectation may, therefore, provide information on the possible effects of the supplementary DNA on these aspects of the phenotype.

As for investigating the relation between quantitative DNA variation and the expression of phenotypic characters other than the viability of gametes and of zygotes the approach was as follows. Suppose, by way of illustration, that the high DNA parent were early flowering and the low DNA parent late flowering. Assuming (a) that the DNA sequences which make up the supplementary DNA in the high DNA parent have no effect upon flowering time, we should expect no correlation between DNA amount and flowering time within backcross or $F_{2}$ progenies. Assuming, (b) that the DNA sequences which make up the supplementary DNA in the high DNA parent 

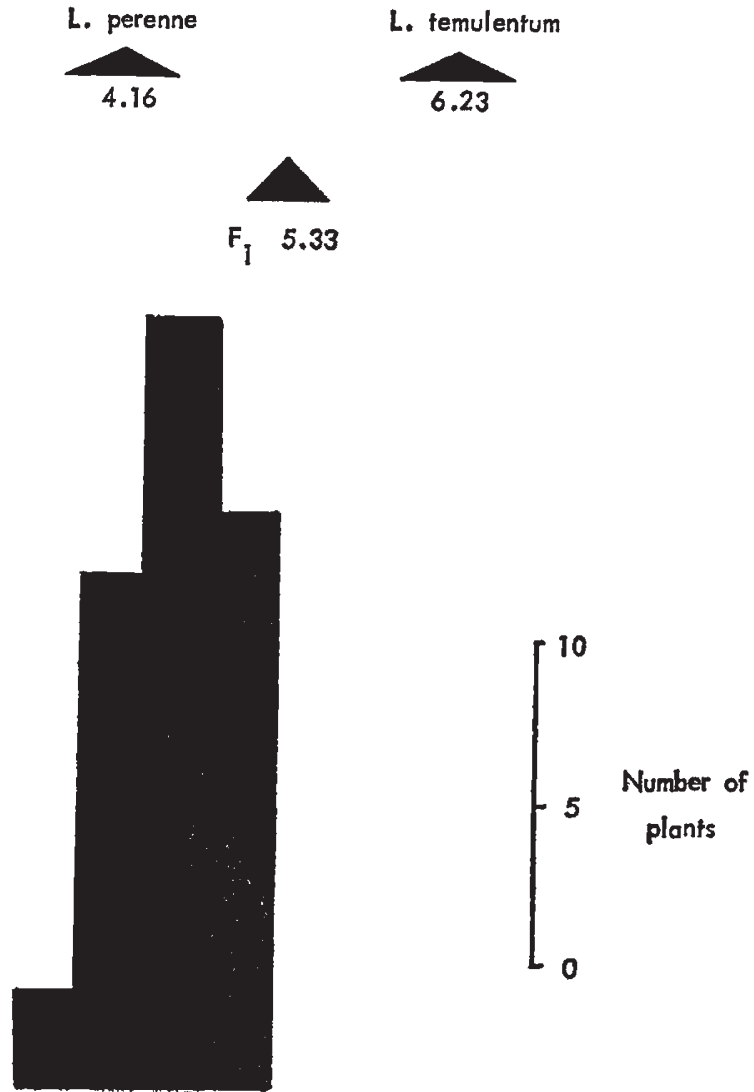

L. temulentum

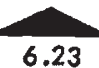

$\begin{array}{lllllllllllll}3.3 & 3.7 & 4.1 & 4.5 & 4.9 & 5.3 & 5.7 & 6.1 & 6.5 & 6.9 & \text { DNA (p.g.) }\end{array}$

Fig. 1.-DNA amounts per $2 \mathrm{C}$ nucleus in $L$. temulentum, L. perenne, the $\mathrm{F}_{1}$ hybrid between $L$. temulentum and $L$. perenne and in the progeny of the backcross (L. temulentum $\times$ L. perenne) $\times$ L. perenne.

contribute directly to the expression of early flowering, we should expect, in this case, correlations between DNA amount and flowering time within backcross and $F_{2}$ progenies (see Rees and Jones, 1967). If the effects of these sequences were additive and of comparable degree to those in other chromosome segments then the correlation would be linear.

We have to make one important qualification to the statements in (b) above. The qualification has to do with the possibility of a correlated response due to close linkage between structural genes affecting flowering time and the DNA sequences which make up the supplementary DNA. Thus, if the supplementary DNA were interspersed with genes of more ancient lineage, which affected flowering time, their effects would be confounded and correlations of the kind discussed could arise even though the supplementary DNA sequences, in themselves, had no effect whatsoever upon flowering time. We are aware that the simple models we have invoked, are only two of many possibilities-bearing in mind the possibilities of many 
different kinds of gene action, interaction and of widely different patterns of gene distribution. Basically, however, our means for establishing an effect upon the phenotype by determinants within chromosome segments carrying the supplementary DNA rests on demonstrating a significant correlation between DNA amount and the variation in phenotype within $F_{2}$ and backcross progenies.

\section{(ii) The characters}

Seeds of the progeny populations, together with the parental species, were germinated in petri dishes before being transplanted, first, into multipot trays and later into pots of diameter $18 \mathrm{~cm}$ in John Innes No. 3 soil. A completely randomised design was used throughout. Morphological and other characters were scored in 40 plants in each of the parental species, although the numbers of plants scored in the different $F_{2}$ and backcross populations were limited by shortage of seeds from some of the crosses.

Many of the characters chosen are under additive polygenic control. Examples of these are seedling leaf number, tiller number, length of fifth leaf (Hayward and Breese, 1966) and date of ear emergence (Cooper, 1959, 1961).

The various characters were scored as follows:

1. Leaf numbers per seedling

2. Tiller numbers per seedling

3. Leaf number

4. Tiller number

5. Leaf number increase

6. Tiller number increase

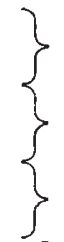

Scored 36 days after sowing.

Scored 49 days after sowing.

Difference between 1 and 3, or

2 and 4 above.

7. Height in $\mathrm{cm}$ of plant 20 weeks after sowing, following winter growth.

8. Flowering date measured as the date of emergence of the inflorescence in days after 1st April.

9. Height in $\mathrm{cm}$ at flowering.

10. Flag leaf length

11. Flag leaf width

12. Spike length $(\mathrm{cm})$

13. Numbers of spikelets per spike

14. Spikelet length $(\mathrm{mm})$

15. Glume length $(\mathrm{mm})$

16. Spikelet/glume length ratio

17. Number of florets per spikelet

18. Pollen stainability-the aborted and non-aborted pollen was stained using the procedure of Alexander (1969): 500 pollen grains were scored in each of two anthers per spike and two spikes per plant. Mean data are presented.

19. Chiasma frequency-the first inflorescences to emerge were fixed in Carnoy's solution. Chiasma frequency at Metaphase I was scored in 20 pollen mother cells from acetocarmine stained squash preparations.

(iii) Technical methods

(a) Crossing and embryo culture

The methods used were essentially the same as those described by Evans and Macefield (1973). Crosses were made in all combinations between two 
inbreeding species ( $L$. temulentum and $L$. remotum) and three outbreeding species (L. perenne, L. multiflorum and L. rigidum). Embryo culture was not required for crosses within the outbreeding group of species, or within the inbreeding group. $F_{1}$ 's were produced from all species combinations, but the different $F_{1}$ hybrids showed varying degrees of fertility (see table 2). For this

TABLE 2

Fertility of Lolium $F_{1}$ hybrids, under the present experimental conditions

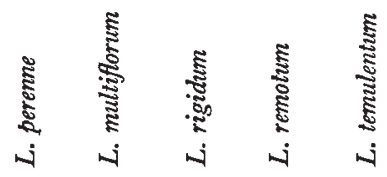

$$
\begin{aligned}
& \begin{array}{llllll}
\text { L. perenne } & - & - & - & - & - \\
\text { L. multiflorum } & \text { F } & - & - & - & - \\
\text { L. rigidum } & \text { F } & \text { F } & - & - & - \\
\text { L. remotum } & \text { MS } & \text { S } & \text { F } & - & - \\
\text { L. temulentum } & \text { MS } & \text { LF } & \text { F } & \text { F } & \text { - }
\end{array} \\
& \mathrm{S}=\text { completely sterile } \text {. } \\
& \text { MS }=\text { male sterile. } \\
& \mathrm{LF}=\text { low male fertility. } \\
& \mathrm{F}=\text { fully male and female fertile. }
\end{aligned}
$$

reason, only a few seeds of either $\mathrm{F}_{2}$ 's or backcrosses were produced from many of the cross combinations.

\section{(b) DNA measurements}

DNA measurements in root meristem nuclei at late telophase or early interphase were made by Feulgen Photometry using a Vickers M85 microdensitometer. The method used was described in detail by Teoh and Rees (1976) and consisted of a double fixation, followed by cold hydrolysis in

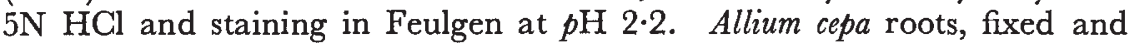
stained at the same time were used as controls for the measurements of DNA quantities of the different Lolium species, while $L$. temulentum was used as control for the measurements of DNA among the progeny populations.

An experiment involving 30 plants showed no significant differences in DNA amount between roots from the same plant. For this reason the DNA amount was scored in one root only of each plant. As the DNA measurements are time consuming, this enabled us to score more plants of each progeny.

\section{Results}

\section{(i) DNA Segregation in backcrosses and $F_{2}$ 's}

(a) The backcrosses. Fig. 1 shows the DNA amounts in Lolium perenne, $L$. temulentum, the $L$. temulentum $\times L$. perenne $\mathrm{F}_{1}$ hybrid and in the progeny of the backcross $F_{1} \times L$. perenne. The parents differ by roughly 40 per cent and the $F_{1}$ mean corresponds closely with the expected mid-parent value. The nuclear DNA amounts among backcross individuals range from that in the low DNA parent to that of the mid-parent value. As we have explained earlier, the range is to be expected, following recombination at meiosis in the $F_{1}$. The distribution of DNA amounts within the backcross tends to the 
normal. In other backcrosses (table 3) the DNA distributions overall do not differ significantly from that in fig. 2. It will be observed, however, that in the backcross of $L$. temulentum/L. multiflorum $\times L$. multiflorum, the mean DNA amount of the backcross progeny is significantly lower than the mid-parent value (table 3 ). This suggests a selection against higher DNA amounts. Whether the selection operates against gametes or against zygotes with high DNA amounts is not known.

Our main conclusion from these backcross results is that the gametes produced by the $F_{1}$ and the zygotes resulting from fertilisation are both viable and effective despite a massive variation in nuclear DNA content.

TABLE 3

Comparison of observed mean DNA amount per plant amongst the progeny populations with the expecied mid-parent $D N A$ amount

\begin{tabular}{|c|c|c|c|c|}
\hline Progeny population & $\begin{array}{l}\text { Number of } \\
\text { plants }\end{array}$ & $\begin{array}{c}\text { Observed mean } \\
\text { DNA per plant } \\
\text { pg per } 2 \mathrm{C} \\
\text { nucleus }\end{array}$ & $\begin{array}{c}\text { Expected } \\
\text { mid-parent } \\
\text { DNA } \\
\text { amount }\end{array}$ & Probability \\
\hline $\begin{array}{l}\text { Backcross } \\
\text { (L. temulentum } \times \text { L. perenne })\end{array}$ & & & & \\
\hline $\begin{array}{l}\quad \times \text { L. perenne } \\
\text { (L. temulentum } \times \text { L. multi- }\end{array}$ & 61 & $4 \cdot 64$ & $4 \cdot 68$ & NS \\
\hline & 19 & $4 \cdot 51$ & $4 \cdot 79$ & $<0.01$ \\
\hline$\times L$. perenne & 33 & $4 \cdot 60$ & $4 \cdot 63$ & NS \\
\hline $\mathrm{F}_{2}$ progenies & & & & \\
\hline $\begin{array}{l}\text { L. temulentum } \times L . \text { rigidum } \mathrm{F}_{2} \\
\text { L. temulentum } \times \text { L. multi- }\end{array}$ & 67 & $4 \cdot 82$ & $5 \cdot 28$ & $<0.01$ \\
\hline $\begin{array}{l}\text { florum } \mathrm{F}_{2} \\
\text { L. remotum } \times \text { L. rigidum } \mathrm{F}_{2}\end{array}$ & $\begin{array}{r}9 \\
32\end{array}$ & $\begin{array}{l}5 \cdot 16 \\
4 \cdot 88\end{array}$ & $\begin{array}{l}5 \cdot 27 \\
5 \cdot 19\end{array}$ & $\begin{array}{r}N S \\
<0.01\end{array}$ \\
\hline
\end{tabular}

(b) $F_{2}$ 's. We have plotted in fig. 2 the DNA distribution within the $\mathrm{F}_{2}$ produced from the cross $L$. temulentum $\times L$. rigidum, along with the DNA distributions within parents. This $F_{2}$ is presented because, as in the case of the backcross in fig. 1, it contains the most individuals. It shows ample evidence of DNA segregation among the $F_{2}$ population. The $F_{2}$ values range, as might be expected, from that in the outbreeding $L$. rigidum to that in the inbreeding $L$. temulentum. They tend to a normal distribution although there is some indication of a dearth of $F_{2}$ individuals with DNA values above the mid-parent values. This is confirmed by the reduction in mean DNA amount in the $F_{2}$ compared with the mid-parent value (table 3 ).

DNA distributions among the other $\mathrm{F}_{2}$ 's conform to those from the $L$. temulentum $\times L$. rigidum cross. The values range from the low to the high DNA parent values in each case. It will be seen from table 3 that the mean is also significantly lower than the mid-parent value in the $L$. remotum $\times L$. rigidum $\mathrm{F}_{2}$.

In the L. temulentum $\times L$. multiflorum $\mathrm{F}_{2}$ the mean, although lower, is not significantly lower than the mid-parent value. The conclusions to be drawn from the $F_{2}$ results are the same as from the backcrosses. First, there is a remarkable tolerance both by gametes and zygotes of a massive nuclear DNA variation. Second, there is evidence for a small but significant effect of selection against either gametes or zygotes with high nuclear DNA 


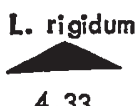

4.33
L. temulentum

6.23

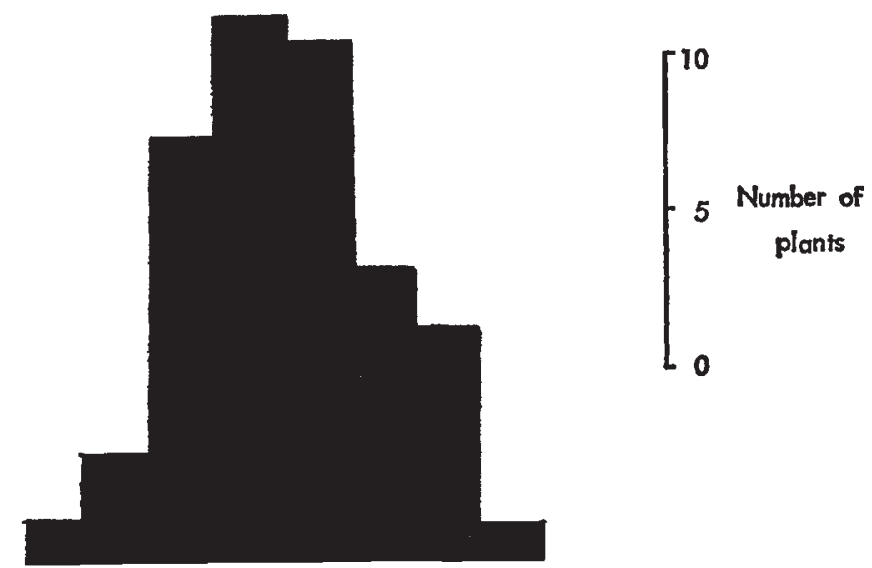

$\begin{array}{llllllllllll}3.3 & 3.7 & 4.1 & 4.5 & 4.9 & 5.3 & 5.7 & 6.1 & 6.5 & 6.9 & \text { DNA } & \text { (pg) }\end{array}$

Fig. 2.-Distribution of DNA (pg per 2C nucleus) among the $\mathrm{F}_{2}$ progeny of the cross $L$. temulentum $\times$ L. rigidum.

amounts in some of the crosses. From this we conclude that the segments carrying the supplementary DNA may not be entirely inactive. We cannot be sure, however, whether the activity is directly attributable to the base sequences which make up the supplementary material or whether the activity is the outcome of structural genes interspersed within it.

\section{(ii) $D \mathcal{N A}$ amounts and variation in phenotype}

In the parent, backcross and $\mathrm{F}_{2}$ families 19 morphological and other phenotypic characters were investigated. For most of these characters there are substantial and highly significant differences between the parents. In table 4, we present the correlation coefficients between the variation for each character and the DNA amount in the backcross and $F_{2}$ families. Of the 91 correlation coefficients only four are significant, a result that may be attributed reasonably to chance alone. Typical examples of the relationships are shown in fig. 3 . On this evidence the chromosome segments which carry 


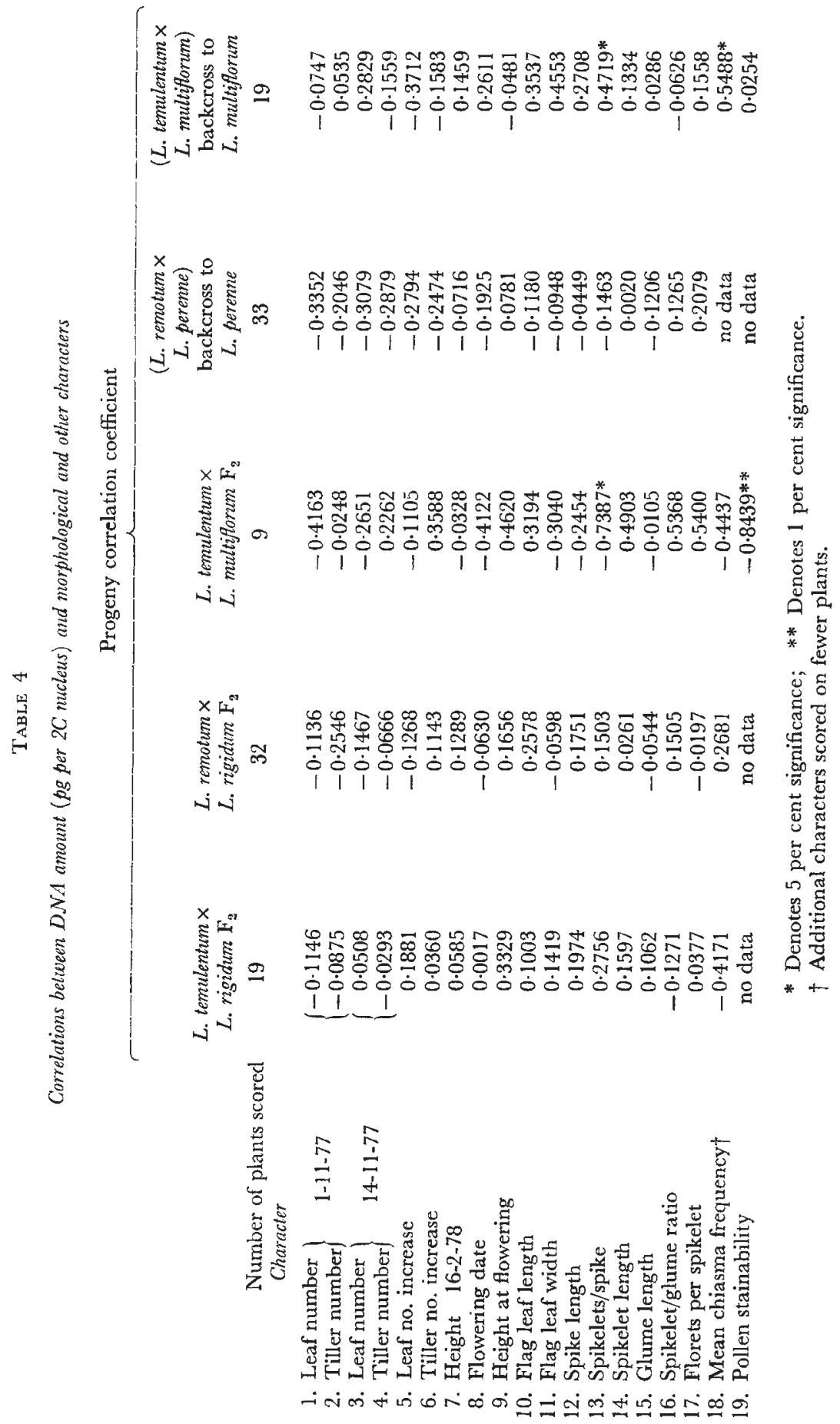



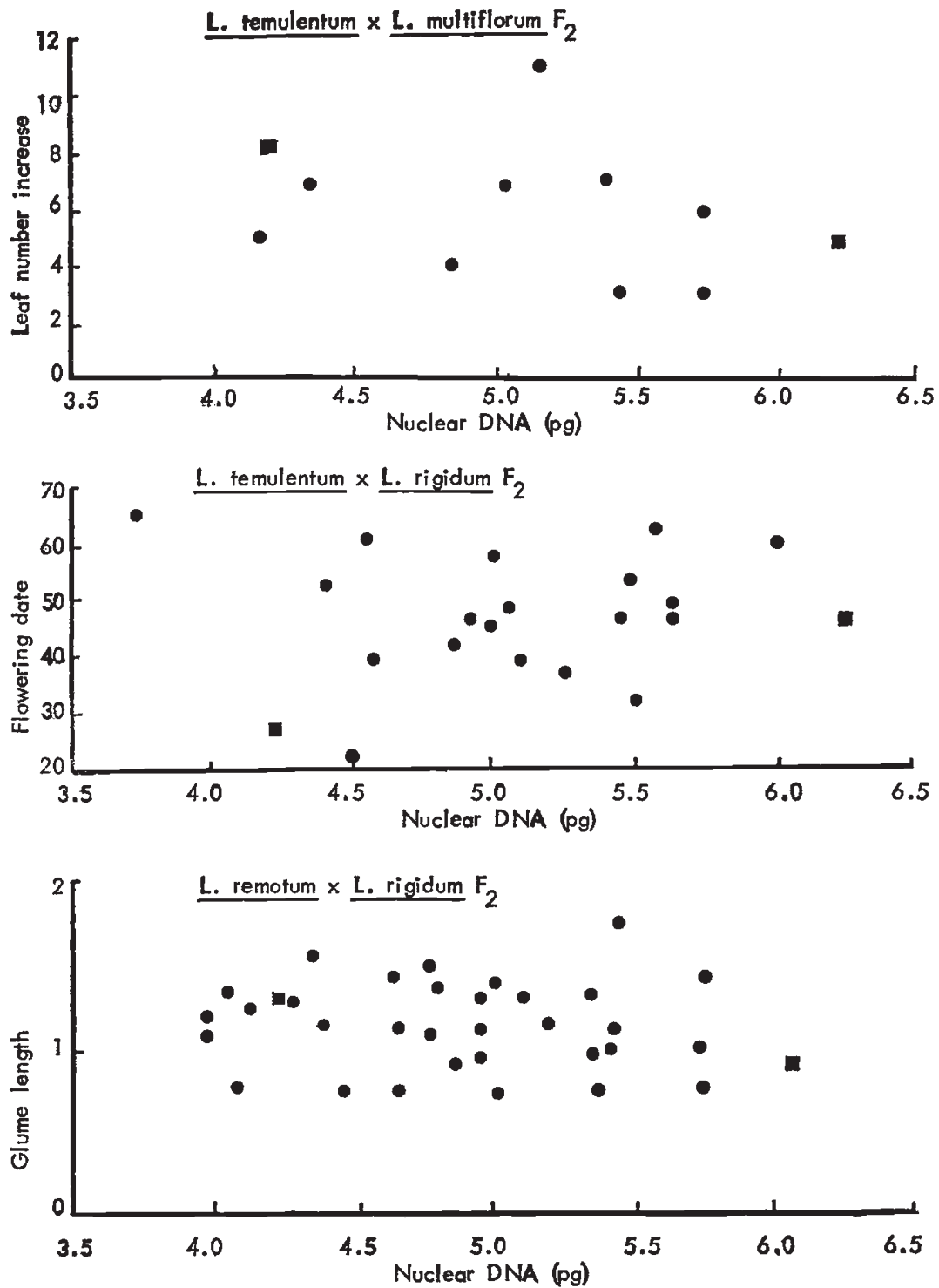

FIG. 3.-Variation in morphological characters with change in nuclear DNA amount. Data plotted for three typical $F_{2}$ populations. Mean scores for parental species are also marked on the graph (squares).

the supplementary DNA have no discernible effect upon the expression of the many characters investigated.

\section{Discussion}

Most of the supplementary DNA in the inbreeding species of Lolium, about 40 per cent, is comprised of moderately repetitive DNA base sequences (J. Hutchinson, unpub.). For this reason we might not have expected evidence for conspicuous activity of the kind associated with structural genes, 
because most of the sequences transcribed and translated to protein are nonrepetitive. At most, only a few per cent of the repetitive sequences are transcribed to messenger RNA (see for example, Davidson, 1976). Even so, it is difficult to accept that this massive supplementary DNA fraction in the inbreeding Loliums, a 40 per cent increment over the nuclear DNA amount in the outbreeders, is completely " inert ". Yet, in so far as our experimental results go, there is certainly no evidence to the contrary-save for the significant reduction in gamete or zygote viability in some backcross and $F_{2}$ hybrid derivatives. We should like, once again however, to point out that in all cases the reduction is slight. What needs to be emphasised is the surprising tolerance of a massive variation in DNA amount in both backcrosses and $F_{2}$. From the standpoint of gamete and seedling viability the effect of the supplementary DNA is, at most, inconsiderable.

We have failed to demonstrate any effect of the supplementary DNA upon a wide variety of other characters of the seedling and adult plant phenotype. Are we justified, therefore, in concluding that this supplementary material has negligible effects upon growth and development, that it is of little genetic significance? There is one fact which suggests it may be wrong to do so. Despite the widespread and large-scale quantitative DNA variation among species, there is little or no DNA variation reported within species. If the constraint upon the DNA variation within species is a consequence of selection it follows that the supplementary DNA cannot be genetically inert. If this argument is to be sustained, however, how do we explain our failure to demonstrate, by assay, any effects upon the phenotype due to the supplementary DNA? In the first place it is possible that the experiments were on too small a scale and therefore lacked the precision for detecting minor changes in growth and development, minor changes which might, however, profoundly influence fitness and adaptation. A restriction upon scale, of course, was the need for measuring the DNA amount in each backcross and $\mathrm{F}_{2}$ individual. A second possibility is that a more effective assay would be achieved by concentrating upon a particular fraction of the supplementary DNA rather than deal with the whole. In this respect it is instructive to recall the work of Hewitt and John (1968) and of Southern (1970). These authors described how supernumerary heterochromatic chromosome segments in grasshoppers affected chiasma frequencies throughout the chromosome complement at meiosis in spermatocytes. If the heterochromatic segments are indeed supernumerary they must consist of supplementary DNA sequences with distinctive genetic effects. It may be worthwhile emulating the approach of the authors above in Lolium and other comparable cases, viz. by identifying a particular fraction of the supplementary DNA, either visually as with heterochromatin or chemically, e.g., by in situ hybridisation, and to search for effects directly associated with its transmission. Until this is done it would be unwise to dismiss the supplementary DNA as genetically inert and redundant. Bearing in mind the massive amount of such material in Lolium we have to concede, however, that its genetic effects upon growth and development are, at most, surprisingly slight.

Finally, in connection with the contrast between the constraint upon DNA variation within species and the massive variation between species in many genera, there are strong grounds for believing that "speciation" in these cases may well be a sudden, cataclysmic event, an event associated with, 
perhaps even dependent upon, a massive reorganisation of the chromosomal DNA.

Acknowledgments.-We are grateful to Dr A. Durrant for advice on statistical matters and to $\mathrm{Dr}$ J. B. Teoh for permission to make use of some of his data. We thank also the Science Research Council for financial support.

\section{REFERENCES}

ALeXANder, M. P. 1969. Differential staining of aborted and nonaborted pollen. Stain Technology, 44, 117-123.

COOPER, J. P. 1959. Selection and population structure in Lolium. II. Genetic control of ear emergence. Heredity, 13, 445-459.

COOPER, J. P. 1961. Selection and population structure in Lolium. V. Continued response and associated changes in fertility and vigour. Heredity, 16, 435-453.

Davidson, E. H. 1976. In Gene Activity in Early Development, 2nd Edition, pp. 214-217. Academic Press.

EVANS, G. M., AND MACEFIELD, A. J. 1973. The effect of B chromosomes on homoeologous pairing in species hybrids. I. Lolium temulentum $\times$ Lolium perenne. Chromosoma (Berl), 41, 63-73.

GUPTA, P. K., AND REES, H. 1975. Tolerance of Lolium hybrids to quantitative variation in nuclear DNA. Nature, 257, 587-588.

HAYWARD, M. D., AND BREESE, L. 1966. Genetic organisation of natural populations of $L$. perenne. I. Seed and seedling characters. Heredity, 21, 287-304.

HEWITT, G. M., AND JOHN, B. 1968. Parallel polymorphism for supernumerary segments in Chorthippus parallelus (Zetterstedt). I. British populations. Chromosoma (Berl), 25, 319-342.

REES, H., AND JONES, G. H. 1972. The origin of the wide species variation in nuclear DNA content. Int. Rev. Cytol., 32, 53-92.

REES, H., AND JONES, G. H. 1967. Chromosome evolution in Lolium. Heredity, 22, 1-18.

SOUTHERN, D. I. 1970. Polymorphism involving heterochromatic segments in Metrioptera brachyptera. Chromosoma (Berl), 30, 154-168.

TEOH, s. B., AND REEs, H. 1976. Nuclear DNA amounts in populations of Picea and Pinus species. Heredity, 36, 123-137. 